\title{
Tyrosine-Protein Kinase ITK/TSK
}

National Cancer Institute

\section{Source}

National Cancer Institute. Tyrosine-Protein Kinase ITKITSK. NCI Thesaurus. Code C29753.

Tyrosine-protein kinase IT K/TSK (620 aa, $75 \mathrm{kDa}$ ) is encoded by the human ITK gene.

This protein is involved in tyrosine phosphorylation and immunity. 